\title{
Effects of dietary caffeine on the testis of the domestic fowl, Gallus domesticus
}

\author{
R. L. Ax, R. J. Collier and J. R. Lodge \\ Department of Dairy Science, University of Illinois at Urbana-Champaign, \\ Illinois 61801, U.S.A.
}

\begin{abstract}
Summary. Roosters were fed $0.1 \%$ caffeine mixed by weight into a standard ration. With continued dietary caffeine administration, the average fertility of eggs collected for 2 weeks from untreated pullets inseminated with semen from the treated males at 0,7 and 14 days after the start of treatment was $30 \cdot 8,33 \cdot 5$ and $3 \cdot 3 \%$, respectively. After 14 days of treatment fertility was significantly lower $(P<0.001)$ than before $(0$ days $)$ or 7 days after treatment. Semen output and sperm concentration were markedly reduced 17-21 days after treatment, and no semen could be collected from the roosters after they had received caffeine for 30 days. Removal of dietary caffeine resulted in resumption of semen production and a return of fertility to the control level. Testicular histology showed that spermatocyte divisions ceased and spermiogenesis was abnormal, although Leydig tissue and the response of the males to massage for semen collection was not affected. The effects on spermatogenesis and fertility were reversible after treatment for 30 days.
\end{abstract}

\section{Introduction}

Caffeine (1,3,7-trimethylxanthine) and its derivatives have been reported to be mutagenic to bacteria (Demerec, Bertani \& Flint, 1951; Grigg, 1968), yeast (Loprieno \& Schupbach, 1971 ; Fabre, 1972), plants (Kihlman \& Levan, 1949; Yamamoto \& Yamaguchi, 1969), and Drosophila (Andrew, 1959; Mittler, Mittler \& Owens, 1967; Kuhlmann, Fromme, Heege \& Ostertag, 1968). Decreases in litter size and increases in fetal resorption resulted when caffeine was injected into pregnant rodents (Nishimura \& Nakai, 1960; Gilbert \& Pistey, 1973). Dietary caffeine (0.05 and 0.1\%) had no effect on fertility when fed to domestic hens, but a significant increase in embryonic mortality was attributed to caffeine (Ax, Bray \& Lodge, 1974a; Ax, Lodge \& Bray, 1974b). The amount of damage to cells and organisms was found to be dependent on the caffeine dose in all the studies mentioned above. This paper presents the effects of feeding $0.1 \%$ caffeine on the spermatogenesis and fertility of roosters and on the embryonic mortality of their progeny before hatching.

\section{Materials and Methods}

Eight roosters and 120 White Leghorn pullets were housed in individual cages in a $16 \mathrm{hr}$ light:8 hr dark photoperiod. Feed and fresh running water were freely available. The pullets to which the males were to be bred for tests of fertility and of the embryogenesis of their progeny were fed a standard laying ration, and roosters were fed $0 \cdot 1 \%$ dietary caffeine $(1,3,7$-trimethyl 6 -xanthine: Nutritional Biochemicals Corp.) mixed by weight into a standard ration.

Semen was collected twice weekly from all males, and sperm concentration was determined from haemocytometer counts. Pullets were inseminated with semen collected from 4 of the roosters 0 , 7 or 14 days after caffeine had been added to the diet. Eggs were collected daily for 2 weeks after the single insemination. Details of the methods of semen collection, insemination and incubation have been reported previously (Ax \& Lodge, 1975). One rooster was killed at 0,31, 38 and 63 days after the start of the caffeine treatment. Two roosters were fed caffeinated feed for 31 days; they then received 
the standard ration, one for 7 days and the other for 14 days, before being killed. Two roosters were fed caffeinated feed for 35 days followed with the standard ration for 28 days before being killed. Testicular tissue was placed in Bouin's fixative, embedded in paraffin wax and sectioned at $5 \mu \mathrm{m}$. Sections were stained with haematoxylin and eosin and examined under the light microscope.

\section{Results}

Throughout the experiments the average feed consumption/rooster was $145 \mathrm{~g} /$ day and each rooster therefore took $145 \mathrm{mg}$ caffeine/day. As shown in Table 1, the average fertility level of the eggs collected during the 14-day collection period from untreated pullets following a single insemination with semen collected from the treated males was significantly lower, by $\chi^{2}$ analysis (Steel $\&$ Torrie, 1960), 14 days after the start of caffeine treatment. The sperm concentration in semen samples pooled from all roosters remained consistent for 17-21 days after caffeine was added to the ration, but then markedly decreased until by 30 days semen could not be collected (Table 2). After removal of the dietary caffeine, semen was obtained 11 days later and the sperm concentration was normal by 21 days (Table 3 ).

Table 1. Effects of $0.1 \%$ dietary caffeine on rooster fertility and embryonic mortality in eggs collected for a 14-day period following a single insemination

\begin{tabular}{lccccc}
\hline $\begin{array}{c}\text { No. of days of } \\
\text { caffeine feeding }\end{array}$ & No. of eggs & $\begin{array}{c}\text { No. of } \\
\text { fertile eggs }\end{array}$ & $\begin{array}{c}\% \\
\text { fertile eggs }\end{array}$ & $\begin{array}{c}\text { No. of } \\
\text { dead embryos }\end{array}$ & $\begin{array}{c}\text { Embryonic } \\
\text { mortality as \% } \\
\text { of fertile eggs }\end{array}$ \\
\hline 0 & 991 & 306 & $30 \cdot 8$ & 23 & $7 \cdot 5$ \\
7 & 549 & 184 & $33 \cdot 5$ & 10 & $5 \cdot 4$ \\
14 & 634 & 23 & $3 \cdot 3^{*}$ & 4 & $17 \cdot 4$ \\
35 & 361 & 112 & $31 \cdot 0$ & 10 & $8 \cdot 9$ \\
$\begin{array}{l}\text { (+28 days of } \\
\text { no caffeine) }\end{array}$ & & & & & \\
\hline
\end{tabular}

${ }^{*} P<0.001$ when compared to fertility of males before caffeine feeding.

Table 2. Effects of $0 \cdot 1 \%$ dietary caffeine on sperm output and sperm concentration of 8 roosters (samples pooled)

\begin{tabular}{ccc}
\hline $\begin{array}{c}\text { No. of days of } \\
\text { caffeine feeding }\end{array}$ & Semen volume $(\mathrm{ml})$ & $\begin{array}{c}\text { Sperm conc./ml } \\
\text { semen }\end{array}$ \\
\hline-3 & 5.6 & $5.9 \times 10^{9}$ \\
$0^{*}$ & 5.8 & $5.8 \times 10^{9}$ \\
4 & 5.9 & $6.0 \times 10^{9}$ \\
7 & 6.2 & $5.8 \times 10^{9}$ \\
11 & 5.8 & $6.0 \times 10^{9}$ \\
14 & 6.9 & $5.9 \times 10^{9}$ \\
17 & 6.4 & $5.9 \times 10^{9}$ \\
21 & 3.2 & $96.0 \times 10^{6}$ \\
25 & $2 \cdot 2$ & $35.8 \times 10^{6}$ \\
29 & 0.4 & $20.0 \times 10^{6}$ \\
$31-63 \dagger$ & 0.0 & 0 \\
\hline
\end{tabular}

* Caffeine started after collection.

$\dagger$ Roosters killed on Days 31, 38 and 63, or 7 and 14 days after caffeine withdrawal on Day 31.

Examination of histological preparations of the testicular tissue removed from roosters revealed that spermatogenesis was markedly affected by caffeine. After 31 days of treatment few spermatocyte divisions were noted, and little if any spermatogenic activity was observed in the testes of 
roosters treated for 63 days. The testes of the roosters fed the diet containing caffeine for 35 days and then the caffeine-free diet for 28 days appeared to be normal.

Table 3. Effects of withdrawal of $0 \cdot 1 \%$ dietary caffeine on sperm output and concentration of 2 roosters

\begin{tabular}{ccc}
\hline $\begin{array}{c}\text { Days after } \\
\text { caffeine withdrawal }\end{array}$ & Semen volume $(\mathrm{ml})$ & $\begin{array}{c}\text { Sperm conc./ml } \\
\text { semen }\end{array}$ \\
\hline 2 & 0 & 0 \\
4 & 0 & 0 \\
7 & 0 & 0 \\
9 & 0 & 0 \\
11 & $1 \cdot 0$ & $10.0 \times 10^{6}$ \\
13 & $1 \cdot 2$ & $2.2 \times 10^{9}$ \\
17 & $1 \cdot 4$ & $3.3 \times 10^{9}$ \\
19 & $1 \cdot 2$ & $4.9 \times 10^{9}$ \\
21 & $1 \cdot 3$ & $5.8 \times 10^{9}$ \\
23 & $1 \cdot 2$ & $6.2 \times 10^{9}$ \\
25 & $1 \cdot 2$ & $6.4 \times 10^{9}$ \\
$28^{*}$ & $1 \cdot 2$ & $6.4 \times 10^{9}$ \\
\hline
\end{tabular}

* Roosters killed on Day 28.

Before killing the roosters receiving caffeine for 35 days followed by the control diet for 28 days, semen was collected and 36 pullets were inseminated. Fertility and embryonic mortality results from 361 eggs collected over a 14-day period showed that there were no significant differences compared to those from eggs of pullets inseminated with semen from the roosters before the caffeine treatment started (Table 1). It therefore appears that the detrimental effects of dietary caffeine on spermatogenesis in roosters are reversible, at least for the times studied in the present experiment.

The roosters responded to manual stimulation and attempted to ejaculate for 63 days while receiving caffeine. The number of Leydig cells remained consistent in testicular sections. Therefore spermatogenesis, rather than ejaculatory response, was inhibited by caffeine. Trace amounts of fluid obtained after sperm depletion were regarded as lymph transudate and an artifact of massage collection (Lake \& El Jack,!1965).

\section{Discussion}

The depressive effect of caffeine on spermatogenesis in this study agrees with the findings of Andrew (1959) on Drosophila. The marked decrease in the percentage of fertile eggs resulting from inseminations with semen from the treated roosters before the observed decrease in sperm concentration suggests that sperm maturation or spermiogenesis was influenced as well as spermatogenesis. Spermatogenesis from meiotic prophase until spermatozoa pass through the lumen of the seminiferous tubules in roosters has been reported to take 12-13 days (de Reviers, 1968), and an additional 3 days are necessary for passage through the rest of the male reproductive tract. The differences in embryonic mortality in this study were not statistically significant, even though the $17 \cdot 4 \%$ mortality in embryos resulting from inseminations with spermatozoa collected from roosters which received caffeine for 14 days was twice as high as the loss of embryos resulting from insemination with spermatozoa collected at the other times (Table 1). The lack of statistical significance was probably due to the low number of fertile eggs. The progressive decrease followed by complete cessation of sperm concentration in semen collections may have been due to caffeine effects on the meiotic cell divisions, since chromosome clumping at the first meiotic prophase of spermatogenesis has been reported (Slizynski, 1971).

Semen production returned to normal after removal of caffeine from the diet, and the normal histological appearance of the testes without a depressing effect on ejaculatory response supports 
the hypothesis that caffeine acts by genetic damage to cells replicating DNA, if it is assumed that caffeine is dispersed freely in the intracellular water of all tissues (Axelrod \& Reichenthal, 1953), including testicular tissue in this study.

We thank Dr D. J. Bray for the roosters and Dr A. V. Nalbandov for the pullets for insemination. This work was supported in part by the Illinois Agricultural Experiment Station, and was performed as part of the M.S. thesis of R. L. A.

\section{References}

ANDREW, L.E. (1959) The mutagenic activity of caffeine in Drosophila. Am. Nat. 93, 135-138.

Ax, R.L. \& LodGe, J.R. (1975) Rooster spermatozoan motility, forward progression and fertility following storage at $25^{\circ}, 5^{\circ}$ or $-196^{\circ} \mathrm{C}$ in various extenders. Cryobiology 12, 93-97.

Ax, R.L., BRAY, D.J. \& Lodge, J.R. (1974a) Effects of dietary caffeine on fertility and embryonic loss in chickens. Poult. Sci. 53, 428-429.

Ax, R.L., LoDge, J.R. \& BRAY, D.J. (1974b) Increased embryonic loss from $0.05 \%$ dietary caffeine. Poult. Sci. 53, 830-831.

Axelrod, J. \& Reichenthal, J. (1953) The fate of caffeine in man and a method for its estimation in biological material. J. Pharmac. exp. Ther. 107, 519-523.

Demerec, M., Bertani, G. \& Flint, J. (1951) A survey of chemicals for mutagenic action on E. coli. Am. Nat. 83, 119-136.

De Reviers, M. (1968) Determination de la durée des processus spermatogénètiques chez le coq a l'aide de thymidine tritiée. Proc. 6th Int. Congr. Anim. Reprod. \& A.I., Paris 1, 183-184.

FABRE, F. (1972) Relation between repair mechanisms and induced mitotic recombination after UV irradiation in the yeast Schizosaccharomyces pombe. Effects of caffeine. Molec. gen. Genet. 117, 153166.

Gilbert, E.F. \& Pistey, W.R. (1973) Effect on the offspring of repeated caffeine administration to pregnant rats. $J$. Reprod. Fert. 34, 495-501.
Grigg, G.W. (1968) Caffeine-death in Escherichia coli. Molec. gen. Genet. 102, 316-335.

Kinlman, B.A. \& Levan, A. (1949) The cytological effect of caffeine. Hereditas 35, 109-114.

KuhlmanN, W., Fromme, H.G., Heege, E.M. \& OstertaG, W. (1968) The mutagenic action of caffeine in higher organisms. Cancer Res. 28, 23752389.

LAKE, P.E. \& EL JACK, M.H. (1965) The origin and composition of fowl semen. In Physiology of the Domestic Fowl, pp. 44-51. Eds C. Horton-Smith \& E. C. Amoroso. Oliver and Boyd, Edinburgh and London.

Loprieno, N. \& SCHUPBaCH, M. (1971) On the effect of caffeine on mutation and recombination in Schizosaccharomyces pombe. Molec. gen. Genet. 110, 348354.

Mittler, S., Mittler, J.E. \& Owens, S.L. (1967) Loss of chromosomes and nondisjunction induced by caffeine in Drosophila. Nature, Lond. 214, 424.

Nishimura, H. \& NAKAI, K. (1960) Congenital malformations in offspring of mice treated with caffeine. Proc. Soc. exp. Biol. Med. 104, 140-142.

SLIZYNSKI, B.M. (1971) Immediate effects of chemicals on mouse chromosomes. 1. Caffeine. Curr. Models Biol. 3, 285-290.

SteEl, R.G.D. \& Torrie, J.H. (1960) Principles and Procedures of Statistics, p. 371. McGraw-Hill, New York.

Yamamoto, K. \& Yamaguchi, H. (1969) Inhibition by caffeine of the repair of gamma-ray-induced chromosome breaks in barley. Mut. Res. 8, 428-430.

Received 24 October 1975 